Juhan Maiste

\title{
ARTISTIC GENIUS VERSUS THE HANSE CANON FROM THE LATE MIDDLE AGES TO THE EARLY MODERN AGE IN TALLINN
}

The notions of Hanseatic trade, Hanseatic culture, the Hanseatic world are so familiar in our everyday parlance, that with no further consideration I have decided to transfer the notion of Hanse to the topic I am dealing with, which is art. In doing this I didn't stop to think what Hanseatic art is actually like, and whether there ever was a time when one and the same visual language was used in the area ruled by the trade empire that existed from the founding of Lübeck in 1159 "als Tor nach Osteuropa", ${ }^{1}$ to the $17^{\text {th }}$ century. So, before tackling the issue of the Hanseatic art canon we should define the idea. What is Hanseatic art, and where and when do we have reason to speak about it without hesitation?

\section{WHAT IS HANSEATIC ART?}

Above all, Hanseatic art is naturally the sum total of the art(s). It is an umbrella notion that covers the language of symbols and forms that germinated over a couple of centuries in northern Europe, linking many different elements and making it possible to treat morphological issues of art (i.e. the vocabulary that relates to art) in one and the

DOI: https://doi.org/10.12697/BJAH.2020.20.02

1 Phillippe Dollinger, Die Hanse (Stuttgart: Kröner, 1989), 10. 
same grammatical key and using the same syntactic rules. The notion of Hanseatic art harbours a number of reefs that existed at a certain time and in a certain geographical area from Bruges and Ghent up to Bergen and Stockholm and Tallinn.

Although homogenous at first sight, there is a lot in the intrinsic ego of Hanseatic art to make one speak in narrow temporal and geographical terms about art in all of its variety in this area. After the emergence of Lübeck the world of Hanseatic trade was divided into eastern and western parts. ${ }^{2}$ Speaking about Baltic identity within Hanseatic art, we traditionally exclude areas to the west of Lübeck and bear in mind the eastern areas more, i.e. Rostock, Wismar, Stralsund, Riga, Tallinn. Here we are speaking about a sphere of spiritual and material culture, something that started with the building of the cathedrals of Ratzeburg, Oldenburg and Hamburg and continued with the construction of St Mary's of Visby and Tartu Cathedral. Side by side with its Backstein-Gotik identity, Hanseatic art has other characteristics such as the use of limestone in the Gothic architecture of Tallinn, or the architecture of the Teutonic Order, which enriched the cultural code of northern Europe in an age in which novel ideas and culture came to Europe in forms that had ripened in the Holy Land and blossomed in Palermo.

So, the notions Hanseatic culture and Hanseatic art as exclusively northern European crumble. What is left is a kind of spirituality that prompted Germanic merchants to sail far into the East to find fame and money in Old Livonia. I am speaking here about a particular type of character capable of survival in harsh and troubled lands. But first I want to speak about a semantic system that is rather difficult to define, an archetype of old forms which in the combination of new humanistic ideas flourished in the frames of Renaissance at the turn of the $15^{\text {th }}$ and $16^{\text {th }}$ centuries.

Speaking about Hanseatic art, I will carry on the tradition established in historical writing. Yet there is a significant difference between Hanse as a trade paradigm and Hanse as a cultural paradigm. If Hanse as it relates to trade means something innovative, then Hanse as it relates to culture must not always carry the same stamp. The ideas of Hanseatic art generally did not mature in the Hanse geographical space but were imported from elsewhere, in the same way that the beads on the necklace of a merchant's wife came from outside that area.

Above all Hanseatic art has the value of a collection. Only being part of such a system, its presence in one and the same treasury or box (the sign of a merchant's wealth) lends meaning to the what is known as the art of the Middle Ages in the Baltic sea area. The sources of Hanseatic art, however, are found somewhere else (for example in Italy, the Netherlands, Spain, etc.), rather than in Hanseatic art itself In order to understand the intrinsic language of Hanseatic art it is necessary to identify its signs, facts and artefacts and bring them to prominence, lifting them out from the context of living history, and, having enriched them with one's glance, return them to their context. In doing so one feels more than just the taste of historical writing, one senses history itself, its pulse and living flesh.

What, then, is Hanseatic art? Can we extend its notion from Bernt Notke's Dance Macabre with all its signs that the art of the Middle Ages up to the altarpiece of Holy Mary of the Brotherhood of Blackheads representing the new trends of Renaissance? Did the atmosphere and spiritual climate of Tallinn and Hanse culture have some role in Michel Sittow's art when he was painting his beautiful Madonnas far away from his hometown? To what extent is it possible to transfer the physical environment to the sphere of culture and the visual arts? And what do they mean in the particular case of some of the most outstanding masterpieces that have survived in old hanse tow Tallinn? To my understanding not everything that forms the essence of an artwork can be read using conventional methods of the stylistic approach but one has to give space to the variety of details and facts hidden in the concrete circumstances of its production.

\section{GOTHIC 'REALISM' VERSUS THE ‘DISGUISED SYMBOLISM OF THE MODERN AGE}

Carsten-Peter Warncke writes in his treatise Sprechende Bilder sichtbare Worte, "The methods and rules of classification of transition from the middle Ages to the Modern Era were not critical-exclusive. On the contrary, as a means of world perception they were directed at illuminating the similarities between parts of the work rather than fixing differences as boundaries. Because of the basically 
instrumental essence of allegorical meaning it was possible for various mixed forms to be developed." ${ }^{3}$ For further discussion have chosen two examples representing the highest level of Estonian art: the main altarpiece of the Holy Spirit church and the altarpiece of the Blackheads, originally ordered for the Dominican monastery and now in St Nicholas church in Tallinn.

First of all let us take under observance the high altar in Holy Spirit church, where nearly all previous investigations have marked the contradiction between the sculptural composition of the central panel dedicated to the Assumption, and the paintings of the wings with scenes from the Holy Elisabeth legend and the Passion of Christ. On one hand we see the new naturalism characteristic to Flemish art of the $15^{\text {th }}$ century, while of the other we have the somewhat esoteric gothic realism familiar in the Hanse world. When choosing dominant images from the age-old treasury of Christian iconography, Notke (masters working at in collaboration with him), apparently quite well informed about northern German taste and cultural space, turns to an artistic approach drawn from the still vigorous stores of illustrative schematism. As Kerstin Petermann has stated we are dealing with two different approaches, and at least two masters. ${ }^{4}$ In comparison to Notke's work as a sculptor whose talent apparently exceeded the traditional level of Hanse art, the paintings demonstrate another kind of approach rooted in quite a different spiritual atmosphere. Instead of a genius, a sort of 'Donatello of the North', we meet a provincial master following ideas and patterns that originated from Lübeckorientated art of the high Hanse period.

When telling the story of St Elizabeth the master is knowingly bridled by tradition. An old story from Dominican hagiographer Dietrich von Apolda is told in the same mode and shape on 23 panels of the Rood Screen at the Hospital of the Holy Spirit in Lübeck. Although from different periods, the pictorial world of the paintings on the altars of both hospital churches derive from the same sources. They can be understood as a sort of daily bread, known both to the masters and the congregation. There are plenty of other examples too. Similar to the painting by the Elisabeth legend master in Tallinn

3 Carsten-Peter Warncke, Sprechende Bilder - sichtbare Worte. Das Bildverständnis in der frühen Neuzeit. Wolfenbüttlerer Forschungen 33 (Wiesbaden: O. Harrassowitz, 1987), 147.

4 Kerstin Petermann, Bernt Notke. Arbeitsweise und Werkstattorganisation im späten Mittelalter (Berlin: Reimer, 2000), 94
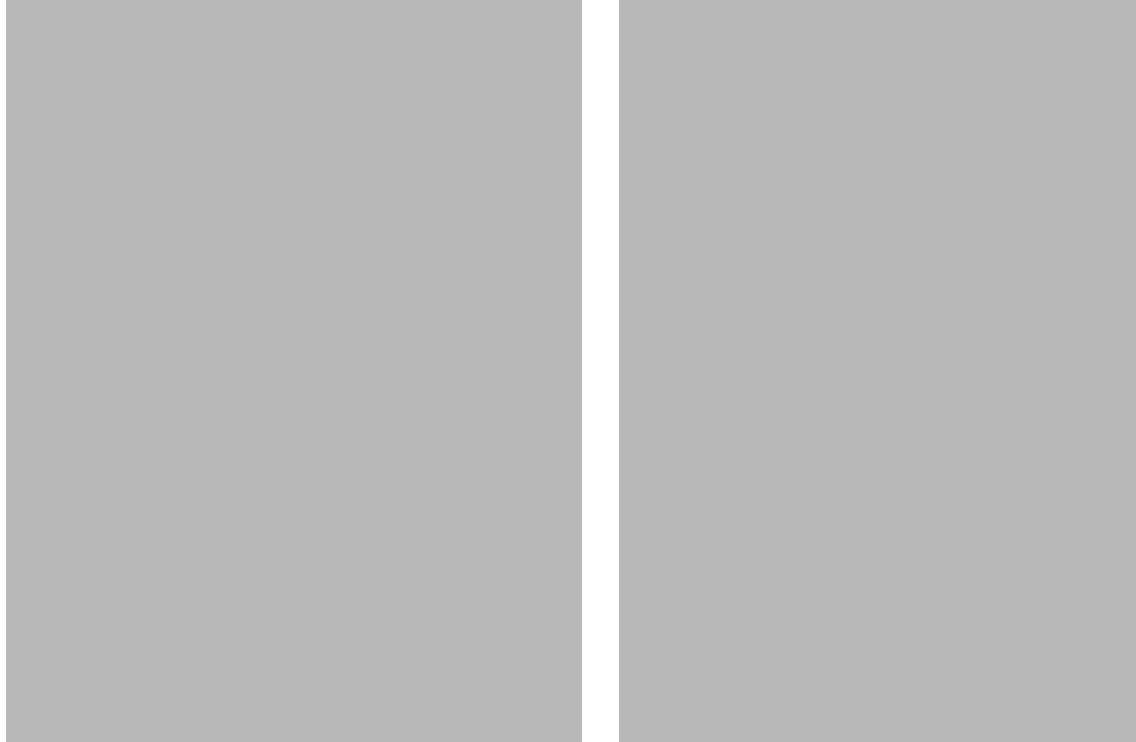

EIG. 1

A HOLY MARIA FROM THE ALTARPIECE BY HUBERT AND JAN VAN EYCK, THE ADORATION OF THE MYSTIC LAMB, CA 1426-1432, ST BAVO CATHEDRAL, GHENT. PHOTO: IEAN-CLAUDE EI (PARIS: TERRAIL, 1997).

B THE PRINCESS FROM THE MONUMENT OF BERNT NOTKE, ST GEORGE AND THE DRAGON, STORKYRKAN (STOCKHOLM), CA 1487. PHOTO: ANDERS QWARNSTRÖM, FROM THE BOOK JAN SVANBERG, SAINT GEORGE AND THE DRAGON (STOCKHOLM: RABÉN PRISMA, 1998), 65

are paintings on the wings of the high altar in in Stralsund's St Nicholas' Church, dedicated to the lives of Saint Anne and Mary. ${ }^{5}$ Apart from the attributes, such as the bedcover and the small dog on the floor, certain features that link Elizabeth and Mary in clothing and physiognomy. And last but not least similar are the rules of construction for the whole narrative, which like the iconography of the composition are within the conceptional scheme of building up the religious space of the Middle Ages.

Speaking about the concept of an image the phantasy of and artist was still limited by numerous taboos and recommendations. In order to be understood by the people gathered in church, Notke as

5 In 1992, the painted wings were taken from the altar and now protrude from the two pillar on the left and right of the altar. 

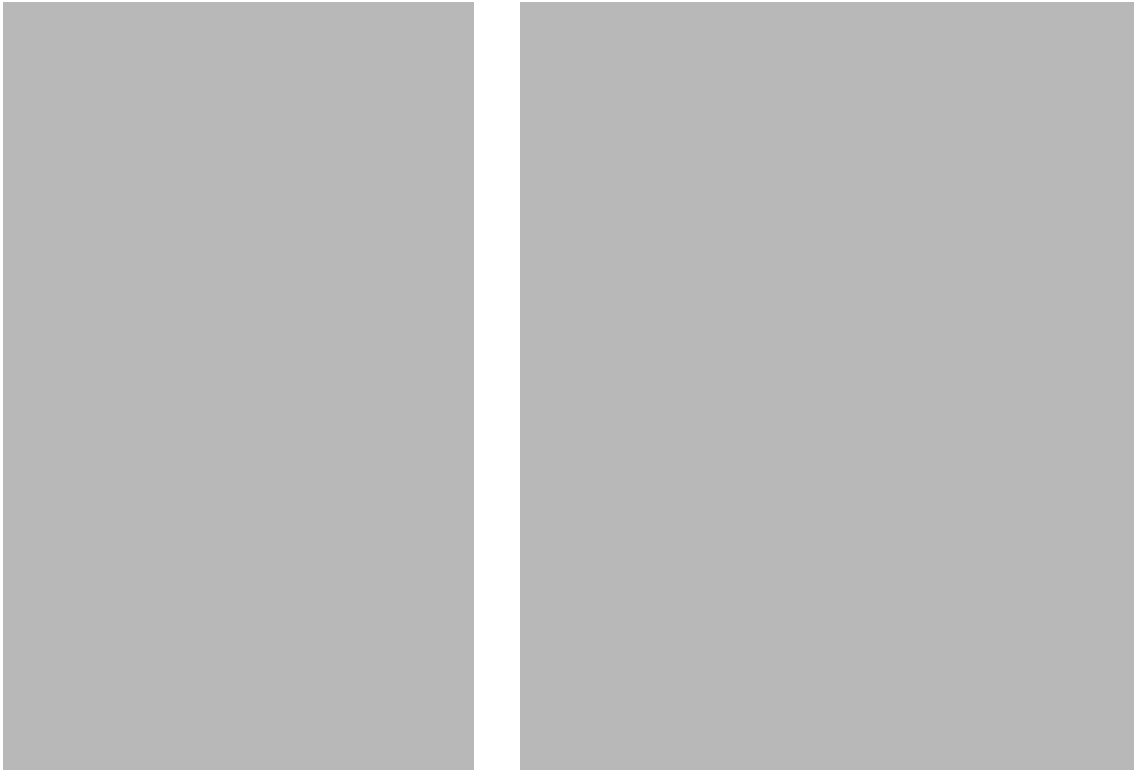

FIG. 2.

A DONATELLO, HEAD OF THE PROPHET HABAKKUK, (1423-1426). MUSEO DELLOPERA DEL DUOMO, FLORENCE. PHOTO: WIKIMEDIA COMMONS

B BUST OF DEAD MAN FROM THE MONUMENT OF BERNT NOTKE, ST GEORGE AND THE DRAGON, STORKYRKAN, CA1487. PHOTO: ANDERS QWARNSTRÖM, FROM THE BOOK BY SVANBERG, SAINT GEORGE AND THE DRAGON.

the leading master needed an alternative, i.e. an artist whose rustic manner, somewhat clumsy and angular, or even old-fashioned, could convince an audience. From one point of view, the work of the genius is orientated to the higher structure of the spiritual hypostasis and the symbolic values of the natural world, while from another point of view the broad patterns of traditional images could easily be understood by the congregation.

In general the images and aesthetic expressions depend on the two different understandings of realism: on one hand from an idealised form of neoplatonic teaching and Flemish painting of the $15^{\text {th }}$ century, and on the other the old fashioned but still living understanding of the world as an arena of supernatural events. The result was a collaboration of different masters and their attitudes towards life, religion and art, with none perceived as better.

As Realism need not always be connected with Naturalism, so the criteria of truth need not always be connected with the need to transmit a message in a language that, since the Renaissance, we have grown accustomed to considering the source of artistic truth. Although often quoted in the study of art of the late Middle Ages and early New Area, there is in most cases no reason to raise the discussion of the individual talent and his genius. The production of artefacts, either in an old Hansa metropole like Lübeck or in the newly flourishing art centres of Bruges, Brussels and Tournai, was generally subordinated to inherited rules that made the role of the individual master (in Greek autochton) of only secondary importance.

\section{IN THE GLARE OF THE METROPOLIS}

Erwin Panofsky describes $15^{\text {th }}$ century Dutch art as allegory, a certain secret code whose "disguised symbolism /---/ due to its respect of the individual raises the picture into the significance of a small world." 6 In contrast to the previous period, in which a picture consisted of representations of quotations from the Bible or the lives of the saints, now truth was used to create understanding of deeper layers of internal vision. Although this still comes as close as possible to previous meanings by repeating original examples devotio moderna i.e. through individual experience. ${ }^{7}$

In this process, in which art plays an important role as the mediator of religion, and the artist takes the role of the demiurge of realism or naturalism, new paths lead to numerous indirect references, which replace previous direct statements, making it possible to read a picture by Robert Campin or Jan van Eyck on two or more levels. Referring to Till Borchert, the school that arose in the Low Countries and the neighbouring areas had no apparent predecessors. ${ }^{8}$ It was the result of an art phenomenon formed by an innovative explosion,

6 Erwin Panofsky, Die altniederländische Malerei, Ihr Ursprung und Wesen (Köln: DuMont Verlag, 2001), 16

7 Jochen Sander, Die Entdeckung der Kunst. Niederländische Kunst des 15. und 16. Jahrhunderts in Frankfurt (Mainz: P. von Zabern, 1995), 33.

8 Till-Holger Borchert, The Age of van Eyck. The Mediterranean World and Early Netherlandish Painting. 1430-1530 (Amsterdam: Ludion, 2002), 9. 
FIG. 3. THE ALTAR OF THE TALLINN BLACK HEADS. SECOND POSITION. THE PATRONAGE SCENE WITH GOD THE FATHER, THE HOLY SPIRIT, CHRIST, THE VIRGIN MARY, SAINT JOHN THE BAPTIST AND THE KNEELING DONORS. PHOTO: STANISLAV STEPAŠKO, 2007.

encompassing Europe from the Iberian Peninsula to the eastern borders of the Roman Empire. From in side th turn of the principles can be distinguished as the result of an innovative explosion and from the other side the continuation of the artistic traditions of the previous times.

From the turn of the $16^{\text {th }}$ century the new approach, rooted in flourishing trade and the art centres of Flanders, also influences the Hanse world, including Tallinn. As examples of the new wave the altar of Christ's Passion in St Nicholas Church in Tallinn with the
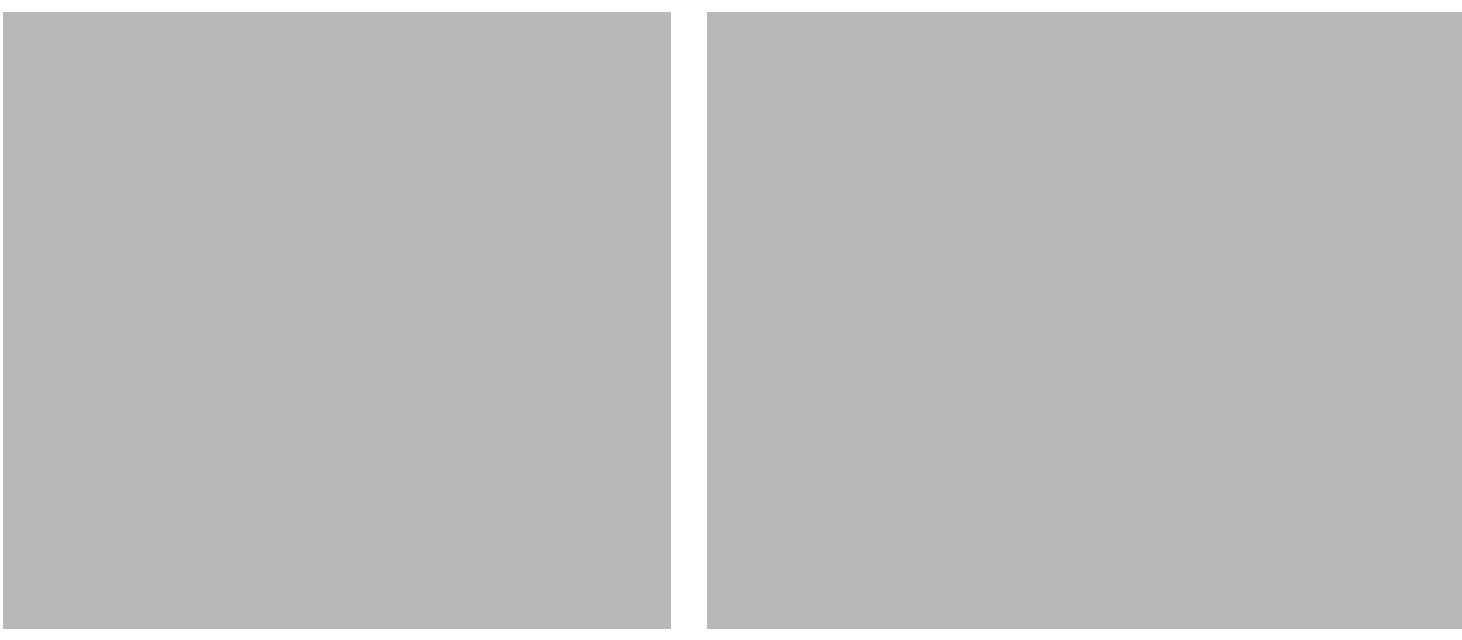

FIG. 4. THE DONATORS FROM THE ALTARPIECE BY THE WORKSHOP OF HANS MEMLINC. THE ALTARPIECE OF THE VIRGIN MARY OF THE BROTHERHOOD OF THE BLACK HEADS. PHOTO: STANISLAV STEPAŠKO, 2006.

over-paintings attributed to Michel Sittow, can be mentioned. ${ }^{9}$ In addition, remark should be made of the altarpiece of Holy Mary, or, as it has also been called, after its commissioner, the Black Heads' altar. According to a document published by Gotthard von Hansen, this was commissioned in 1481 for 20 Riga weight marks and brought to Tallinn via Lübeck from the 'West', then connected to the altarpiece of St Catherine's Church in the Dominican Monastery. ${ }^{10}$

A number of questions arise from this. What does the notion West mean? By whom and under what conditions was the altar constructed and under what conditions did it arrive in Tallinn? As mentioned by Eduard Pabst, the altar was ordered für gemeinsame Kosten d. Grossen

9 Mai Lumiste, "Antoniuse altari algsest maalingukihist ja ülemaalingutest", Kunst, 2 (1964), Juan de Flondes. Drei Maler aus dem Norden am Hof Isabellas von Kastilien (Kiel: Verlag Ludwig 2011), 105f). Helena Risthein "Kannatusaltarist ja frantsiskaanlusest= Über den Passionsaltar und die Franziskaner. Die ursprüngliche Gestalt der Flügelaussenseite", Die Kunstbeziehungen Estlands mit den Niederlanden in den 15.-17. Jahrhunderten. Konferenz 25. 26. September 1995 (Tallinn. Eesti Kunstimuuseum, 2000), 89. Juhan Maiste "A Genius and His Myth. The Known and Unknown Michel Sittow", Baltic Journal of Art History, 9 (2015), 202. 10 Beiträge zur Kunde Ehst-, Liv-, und Kurlands, Band 1, ed. by Eduard Pabst (Reval: Lindfors' Erben, 1869), 6. 
Gilde und der Schwarzenhäupter. The first to connect the altar with Hans Memling was Friedrich Amelung. ${ }^{11}$

Amelung's opinion was supported by Wilhelm Neumann, who attributed the altar to Hans Memling. ${ }^{12}$ Neumann's conclusion was supported by Sten Karling, who writes: "Based on the style, the altar seems to have originated in Bruges /---/ and undoubtedly, those who believe the Black Heads' altar to be associated with Memling himself are right. However, just as correct is the observation that more than one person has participated in the execution of the work. The altar was produced in a workshop, and therefore, its execution is comparatively uneven. Some parts are downright brilliant, but next them, we see parts that are relatively poorly executed. /---/ The donors - a group of members from the Confraternity of Black Heads - are kneeling before the Virgin Mary and John the Baptist. Some of the portraits are wonderfully executed, and closely resemble Memling's penetrating human closeness that is borne by a warmth of heart. The rest, especially Christ with angels, provide an inkling of the style of Memling's closest student from Bruges, the so-called 'Master of the St Lucy Legend'."'13

However, there are other viewpoints. In 1961 Mai Lumiste attributed the entire altar to the master of St Lucy's Legend, ${ }^{14}$ an assumption

11 Friedrich Amelung, Die Memlingische Flügelaltargemälde in Revaler Schwarzenhaupterhausen und deren Kunstsinniger Mitstifter der revaler Grosskaufman

12 Wilhelm Neumann, Grundriss einer Geschichte der bildenden Künste und Kunstgewerbes in Liv- Est-und Kurland vom Ende des 12. bis zum Ausgang des 18. Jahrhunderts (Reval: Fran Kluge, 1887), 103. A few years later the same author still wrote: "Den Meister der schönen Altar müssen wir im Kreise der Nachahmer des Hans Memling suchen, an den er sich augenscheinlich Farbenharmonie zu erreichen. Anlehnungen an ihn finden sich in der Figur des heiligen Johane auf der Mittelbilde mit der thronenden Maria des Johannisaltars im Spital zu Brügge, wie in den Bildern der äusseren Flügel und einigen Köpfen des Altars in der Greveradenkapelle zu Lübeck." (Eugen von Nottbeck, Wilhelm Neumann, Geschichte der Kunstdenkmäler der Stadt Reval, Erste Lieferung, II Theil (Reval: Franz Kluge, 1896), 206.) It is an opinion that quite closely coincides with that of the author of these lines. In 1906, returning to the problem of the Tallinn Black Heads, Neumann has dropped his earlier belief, explaining that the altars of Lübeck and Tallinn have nothing in common (Tallinn City Archives [Tallinna Linnaarhiiv, TLA].87.1.396). On the eve of the Reformation the altar was brought to shelter in the house of the Black Heads from its original location - St Catherine's of Tallinn's Dominican Friary. The history of the reception of the altar offers several interesting legends about its later fate. In 1784 August Kotzebue told the story of how the altar of the Black Heads was taken out of the city by an underground passage to St Bridget convent 5 versts away where he says the monks buried it in 1564 in connection with the burning of the convent (Friedrich Amelung, Revaler Altertümer (Reval: Franz Kluge, 1884), 36.) Today the altar is located in the museum of St Nicholas Church.

13 Sten Karling, Tallinn. Kunstiajalooline ülevaade (Tallinn: Kunst, 2006), 85.

14 Mai Lumiste, "Lucia legendi meistri teos Tallinnas. Mustpeade altari autori problemist", Kunst, 2 (1961), 32-42, here 32. that was also supported by Nicole Veronee-Verhaegen. ${ }^{15}$ Thus, a new myth had seen the light, one that rejected all prior statements. ${ }^{16}$ The third theory subscribes to the idea of several masters working in one and the same workshop at one and the same time, including a pupil of Memling in his elderly days, Michel Sittow ${ }^{17}$, a Tallinn-born artist ${ }^{18}$ who could also have been the mediator between the patrons - i.e. the Black Heads and the merchants of the Great Guild of Tallinn and the artist's studio in Bruges.

In my opinion, the problem of authorship in the $15^{\text {th }}$ century is in most cases only secondary importance. The St Lucy's Legend master is just one of many other unknown masters mentioned by Erwin Panofsky along with the masters responsible for St Catherine's, St Barbara's and St Ursula's Legends, along with the Magdalen Legend master, etc. ${ }^{19}$ Or, as Didier Martens has put it: "The work of the St Lucy's Legend master has remained almost unknown. Despite 100 years of research he has neither become recognised among most art historians, nor has his name been attached to every picture of the Madonna that is not considered worthy of Hans Memling." 20

Still, the more colourful its clothing, the more beautiful art history is. To enjoy the colours and to understand the essence of and artwork

15 Nicole Veronee-Verhaegen, "Un important retable du Maître de la Légende de sainte Lucie conservé à Tallinn”, Bulletin de l'Institut royal du Patrimoine artistique, 4 (1961), 142-154.

16 Anu Mänd, "Tallinna Mustpeade vennaskonna Maarja altarist ja selle ikonograafiast = Über den Marienaltar der Revaler Schwarzenhäupter und seine Ikonographie", Die Kunstbeziehunge (Tallinn: Eesti Kunstimuuseum, 2000), 219-238.

17 Robert Rebas, Der Maler Michel Sittow. Beiträge zur Geschichte der Baltischen Kunst (Giessen: W. Schmitz, 1998), 211-242; Michail Libman, "Michael Sittow, Burgher of Tallin and Court Painter of Queen Isabella of Castile (Additions and Specifications)", Actas del XXIII Congreso Internacional de Historia del Arte. España entre el Mediterráneo y el Atlántico, 2 (1977), 339f; Juhan Maiste, "Die Renaissance in Tallinn. Ein neuer "Stil" in der alten Hansestadt", Finskt Museum 1992 (Helsinki:Vammala, 1994), 26-58, here 38; Juhan Maiste, "A Genius and
His Myth. The Known and Unknown Michel Sittow", 177-224.

18 Paul Johansen, "Meister Michel Sittow, Hofmaler der Königin Isabella von Kastiline und Bürger von Reval", Jahrbuch der Preussischen Kunstsammlungen, 61 (1940), I Heft, 1-36. See also: John Oliver, Greta Koppel, Till-Holger Borchert, Anu Mänd, Ariane van Suchtelen, Matthias Weniger, Michel Sittow. Estonian Painter at the Courts of Renaissance Europe. A Catalogue of an Exhibition (Washington; Tallinn: National Gallery of Art, Washington; Museun of Estonia, 2018)

19 Panofsky, Die altniederländische Malerei, 350

20 Didier Martens, "Der Brügger Meister der Lucialegende. Bilanz der Forschungen und Neue Hypothesen", Die Kunstbeziehungen Estlands mit den Niederlanden in den 15.-17. Jahrhunderten. Konferenz 25.-26. September 1995 (Tallinn: Eesti Kunstimuuseum, 2000), 75. 
one does not necessarily need a microscope (which is actually just an extension of the eye). As complete and rich as it is, art writing is still full of unanswered questions and contradictions that cannot be eliminated with even the most careful sifting. During the heyday of Flemish art, the altars produced by the workshops in Bruges and Brussels covered a territory reaching from Bruges to Toledo and from Lima to Tallinn, establishing a foundation for the development of a cosmopolitan art world, comprised a uniform world where the technical part of art, the techniques in use and even the pattern of images did not allow one master, or even one workshop, to be differentiated from another.

Let us detect some aspects of the altar that have played an important role in the formation of the general picture of the $15^{\text {th }}$ century in the North. From the iconographic point of view we have to admit that both the general composition and the motifs are cut out from an international album full of art from the post-Eyckian tradition on the one hand, and late mediaeval luxury objects characteristic to the Hanse world (including textiles, brocade wallpapers, etc.) on the other. ${ }^{21}$ The middle panel of the altar depicts Mary with Child enthroned. The inner sides of the inner wings have St Francis of Assisi in a festive position demonstrating his stigmata and St Gertrude of Nivelle, each holding a book, quite a rare feature in Tallinn. This is possibly a programmatic requirement from the Dominicans, and as we know the altar was originally commissioned for their monastic church.

The outer wings feature on the inner sides the so-called threefold tutelage scene, with the crowned God the Father as the heavenly ruler and the Holy Spirit hovering above his head in the shape of a pigeon. In the panel furthest left we find the figure of Mary feeding the Child (Maria lactans), something not very usual for the iconography of the time. As a rare object Mary holds in her fingers an amber rosary, probably in a display of local will. She has bared her abnormally high breast (I believe it is a deliberate anatomical deformity) in tutelage of the Black Heads and members of the Great Guild at her feet. The next altar panel features, in varying degrees of artistic quality and message, the figure of a kneeling Christ demonstrating his wounds,

21 Kerttu Palginõmm, "Der dem Meister der Lucialegende zugeschriebene Revaler (Tallinner) Retable - kostbare Stoffe und ein unbekannter Meister?", Baltic Journal of Art History, (2012), $117-143$. with two angels behind his back holding instruments of martyrdom. Instead of the naturalism that dominates in the previous panel there is a clear turn toward schematism both in colour and form. The hero of the third tutelage scene is John the Baptist, a young and handsome man in the style and quality of the school of Hans Memling. The highest quality of the masterpiece is in the figures of the donors (15 +15) on both sides of the inner wings in front of St Mary and St John the Baptist. In this the three figures in the front row on both panels demonstrate the pinnacle of the Bruges school.

Two worlds - mature naturalism in the best tradition of Flandrian illusionism and the shadow of gothic realism - form a unity in which the abstract idea is supported by symbolic artistic detail. The iconographic scheme of the central panel is undoubtedly Flandrian. Mary and Child are borrowed from canon Joris van der Paele's altar (in Groenigemuseum, Bruges), the second greatest Dutch altar after that by Jan van Eyck in Ghent. Long golden locks coming down to the shoulders fall on a soft velvety robe hidden under a black coat. The Child in Mary's arms is naked and joyful to the toes of his feet. A ruler enthroned and bursting with solemnity, the Virgin is depicted in numerous compositions by Memling and his less talented contemporaries, including the master of St Lucy's Legend. Prototypes of Tallinn's Mary include Virgin and Child Enthroned with Saints Catherine and Barbara and Two Musical Angels (after 1479, New York Metropolitan Museum of Art), and John Donne's altar, which is similar in composition (ca 1480, London, National Gallery).

The closest to the altar of the Black Heads is Memling's altarpiece of Saint John the Baptist and Saint John the Evangelist (St John's Altarpiece, 1474-1479, Sint Jans Hospitaal, Bruges), which in my opinion is typical of the author. In contrast to the works mentioned above, the Mary of Tallinn wears a tall bejewelled golden crown This is how she appears in Jan van Eyck's main work, the Ghent altar.

The figure of St Mary is confronted by soldier saints, popular in Tallinn, St Olaf and St Victor (the one of three martyr saints of the same name), both of them clad in armour, as might have been necessary in distant borderland. Once again the figures from the altarpiece of Joris van der Paele (1434-1436) appears before the eyes. And last but not least I would like to draw the attention to the bearded image of God the Father on one of the side wings of the altar of Brotherhood of Blackheads, the type familiar to Notke in his Lübeck 

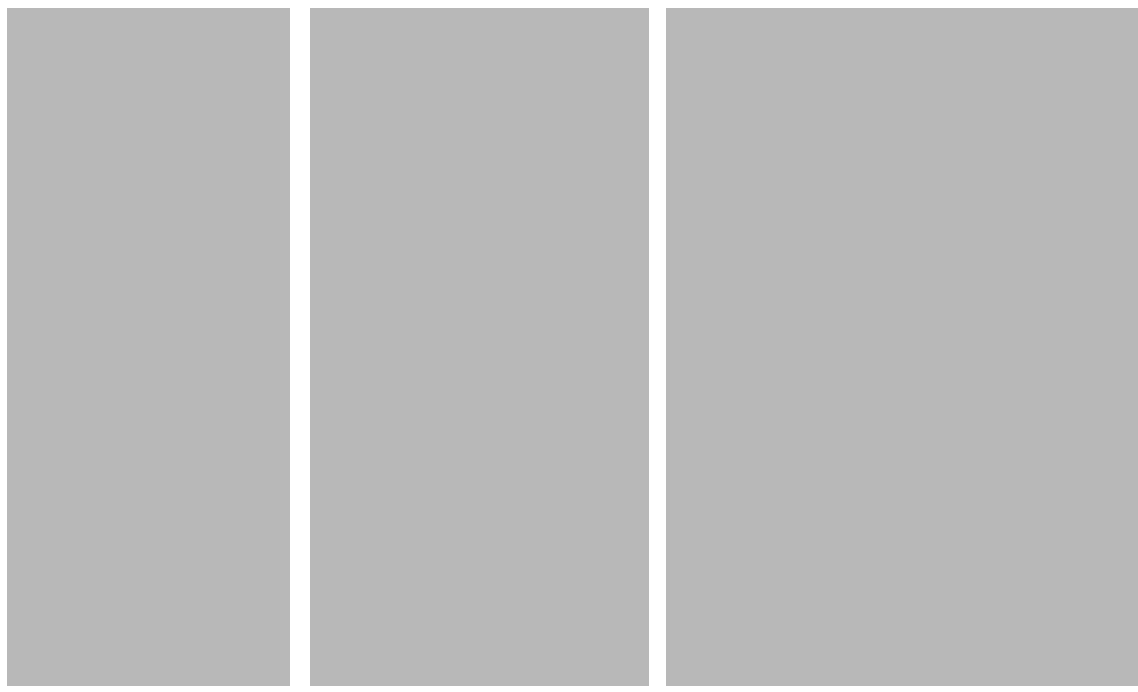

FIG. 5 .

A FIGURES OF POPE AND EMPEROR FROM THE "DANCE OF DEATH" BY BERNT NOTKE, ST NICHOLAS CHURCH (TALLINN). PHOTO: ART MUSEUM OF ESTONIA.

B CORONATION OF THE VIRGIN BY MICHEL SITTOW, CA 1496-1504, LOUVRE, PARIS, PHOTO: HAND, KOPPEL, ET AL., MICHEL SITTOW. ESTONIAN PAINTER AT THE COURTS OF RENAISSANCE EUROPE, 56

Schonenfahrerretabel (Scania Travellers' Retable) as well as in his Danse macabre in the image of the emperor. The same patterns and details can be found in works attributed to the Lucy Legend master. (The altarpiece of St Nicolas at Groeningemuseum in Bruges).

However, in the altar of the Black Heads, God the Father looks somewhat more benevolent and full of grace. His long eyelids are full or tender, sympathy and there is a sort of existential sorrow characteristic to the portraits of Michel Sittow, who at the time the Tallinn altarpiece was ordered, had already established his position as pupil and follower of Memling. ${ }^{22}$ A parallel to the God the Father of the Black Heads altarpiece shows God the Father in one of the most sensitive of Sittow's paintings, Coronation of the Virgin. ${ }^{23}$

22 For more detail see: Johansen, "Meister Michel Sittow, Hofmaler der Königin Isabella von Kastiline und Bürger von Reval", 10.

23 About the Coronation of the Virgin see: Chyo Ishikawa, The Retablo de Isabel la Católica by Juan de Flandes and Michel Sittow (Turnhout: Brepols, 2004), 11.
To solve the problem of distinguishing the handwriting of one master from another one must go beneath the stylistic surface. In the same way that Hans Memling, rising from the German-speaking cultural sphere, could be interpreted as the mediator of the German speaking world, Sittow, who started in Tallinn, could be called ambassador of northern taste and the Hanse tradition. This, even more than the elegance and decorative splendour of the Flemish attitude, emphasised the inner psychological world of the German speaking world described by Erwin Panofsky. ${ }^{24}$

Along with the innovation familiar to the post Eyck'ian school in the art capitals of Flanders and its surroundings, we must not forget the role of the traditional cultural roads that connected Flanders with its historical background of Lübeck and other northern German cities.

\section{RHETORIC OF THE TIME AND ABSORBING THE NEW IDEAS}

When searching for the history of the Italian-originated ars nuova and its counterparts in the North, one has to face the problem of the boundaries of the artistic world. This relates to both the geography and the time, ideas and reflection, light and the shadow it casts far beyond its origin. In 1473 Memling's Last Judgement Altar ended up in Danzig in cargo dispatched by Angelo Tani to Florence. Another piece - a large altar to the Passion theme (the so-called Greverade Triptych) intended for Lübeck Cathedral was completed in Memling's workshop in 1491 and placed in the Cathedral's St Mary's Chapel only in 1504. ${ }^{25}$ According to Max Hasse, the work was completed during complicated times: "Der Bischof Albert Krummedick [who commissioned Bernt Notke's triumphal cross - J.M.] hatte bei Seine Tode 1489 dem Domkapitel eine ungeheure Schuldenlast hinterlassen. /---/ Als um die Jahrhunderwende zuerst Heinrich Greverade und dann auch sein Bruder Adolf starben, wurde aus dem Nachlass Adolfs die Vicarie

24 Erwin Panofsky, The Life and Art of Albrecht Dürer (Princeton: Princeton University Press, 1943). 25 Dirk de Vos, Hans Memling. The Complete Works (Antwerpen: Mercatorfonds Paribas, 
am Dom eingerichtet." ${ }^{26}$ Based on the position of Dirk de Vos, Uwe Albrecht presents another opinion: "Vor 1504 scheint das Retabel noch nicht in Lübeck gewesen zu sein, vielleicht nach dem Tode Hans Memlings vorübergehend in Brügge benutzten Kirche des Karmelitenklosters aufgestellt." 27

It is interesting to add that the mediator of the commission was a man called Hans Pawels. The man with the same name (or the same man) lived in Tallinn in 1492, becoming superior at St Olaf's and the contractor for St Mary's Chapel, one of the biggest building projects at the church. ${ }^{28}$ As pointed out by Friedrich Amelung, Hans Pawels was also the mediator for the order of the Tallinn Black Heads when they ordered the new altarpiece from the West, which arrived in Tallinn via Lübeck. ${ }^{29}$ Wilhelm Neumann pointed out the similarities between Memling's circle and the Greverade altarpiece: "Anlehnungen an ihn finden sich in der Figur des heiligen Johannes auf der Mittelbilde nit der thronenden Maria des des Johannesaltar im Spital zu Brügge, 26 Max Hasse, Hans Memlings Lübecker Passionsaltar (Lübeck: Lübeck Museum für Kuns "Am 30 April 1504 auf Antrags des Neffen und Testamentsvollstreckers Heinrich Greverade und dreier anderer Lübecker Bürger, Hermann Papenbrock, Moritz Loff und und Gottherd Wiggerinck."

27 Uwe Albrecht, Corpus der Mittelalterlichen Holzskulptur und Tafelmalerei in SchleswigHolstein, Band I (Kiel: Ludwig, 2005), 261.

28 As pointed out by Friedrich Amelung, the intermediary for the commission was Hans Pawels, a merchant from Lübeck who bought a house in Tallinn in 1494 and quickly rose to become a member of the town's elite. See: Rasmus Kangropool, "Tallinna hilisgoot etikukividest", Vana Tallinn, IV (VIII) (1994), 7. Twenty years later, Hans Pawels signed contract with Bernt Wolte for the construction of the Chapel of the Virgin Mary in St Olaf Church. His cenotaph, on the eastern wall of the chapel, was completed in the same year. See: Sten Karling, "Die Marienkapelle an der Olaikirche in Tallinn und ihr Bildwerk. Ein Beitrag zur Brabenderfrage", Publications de Cabinet d'historie de l'art de l'universite de Tartu, 1 (1937), 11f. Quite an interesting parallel is provided by another person called Han Pawels, about whom information exists from Lubeck dating from 1469 to 1487 (informatio from Prof. Uwe Albrecht 2006). He may have been, but was not necessarily, a relative of the along with Heinrich Greverade and Heinrich Castorp, was one of the founding members of the Confraternity of the Sacred Cross and builders of the Chapel of the Sacred Cross of Our Lady's Church (completed in 1493), for which a large altar of Christ's Passion was commissioned (Ludwig Kämmerer, Memling (Bielefeld: Velhagen und Klasing, 1899), 130.) Today, this view has been refuted, and instead, "a fairly spectacular theory that on the altar there are depicted three great German painters: Michael Wolgemut, the young Dürer and Memling" has been presented (de Vos, Memling, 326.)

29 Manuscript: AM F237:1.
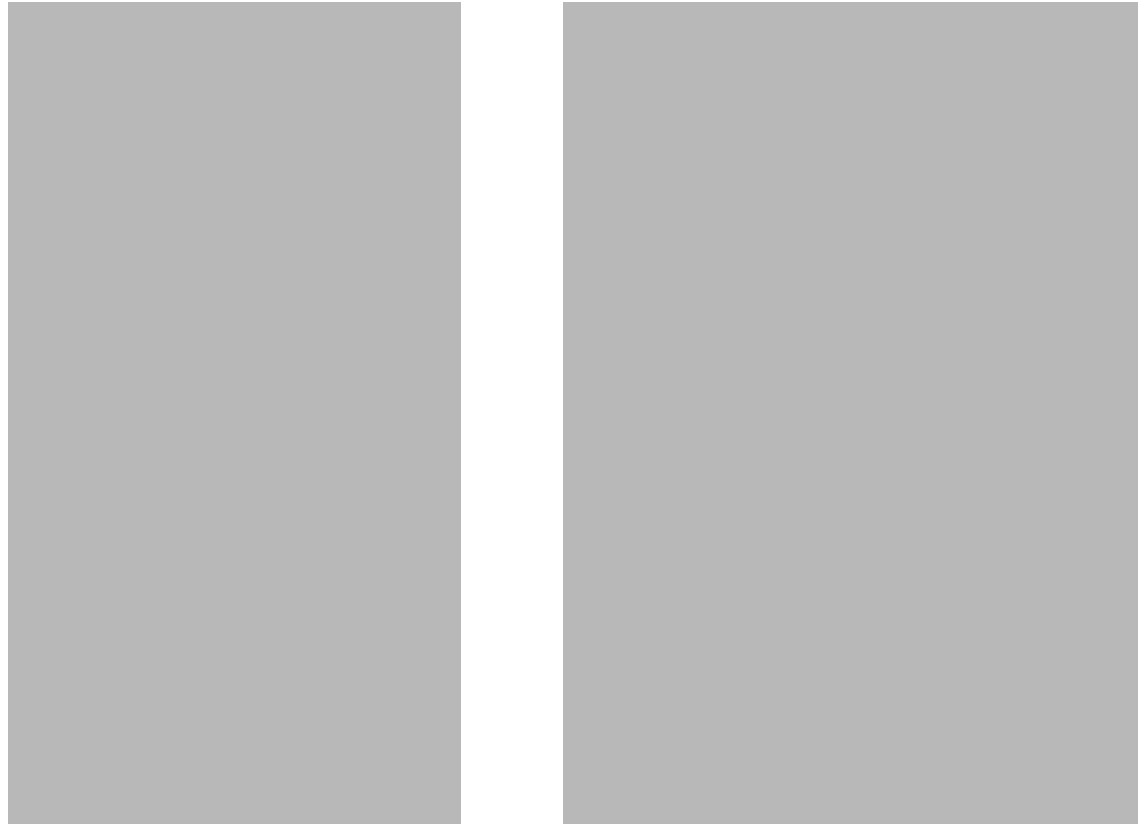

FIG. 6

A ANNUNCIATION. CLOSED VIEW OF TRYPTICH OF THE GREVERADE ALTARPIECE BY HANS MEMLING, CA 1491. ST ANNE S MUSEUM, LUBECK. PHOTO: DIRK DE VOS, HANS MEMLING. THE COMPLETE WORK (LONDON: THAMES AND HUDSON, 1994), 323.

B ANNUNCIATION. ALTAR OF THE VIRGIN MARY OF THE CONFRATERNITY OF BLACK HEADS. IN ST NICHOLAS CHURCH IN TALLINN. PHOTO: STANISLAV STEPAŠKO, 2007.

wie in der äusseren Flügel und einigen Köpfen des Altars in der Greveraden - Kapelle in Lübeck." ${ }^{30}$

First of all, the resemblance concerns the outer wings with grisaille paintings that originally belong to the rhetorical repertoire of the era often used from the time of Jan van Eyck onward (for example, the grisaille Annunciation-themed paintings on Jan van Eyck's Dresden Altarpiece, 1437, Staatliche Kunstsammlungen Dresden). Another remarkable example of the kind is the Triptych of the Burning Bush

30 Neumann, Grundriss einer Geschichte der bildenden Künste und Kunstgewerbes in LivEst- und Kurland vom Ende des 12. bis zum Ausgang des 18. Jahrhunderts, 103. In 1909, when Neumann restored the house of the Black Heads in Tallinn he changed his mind and wrote that he two altars in Lübeck and Tallinn had nothing in common (TLA.87.1.396). 
(1475-1476, Aix Cathed ral, Aix-en-Provence) by Nicolas Froment, the artistic credo and sources of inspiration which can be compared to the Black Heads altar in Tallinn.

"Double-winged altarpieces were common in Germany, but very rare in the Low Countries", states de Vos. ${ }^{31}$ As he suggests, the grisaille panels with the figures of the Archangel Gabriel and the Virgin Mary in the case of the Lübeck altarpiece, are poorer in quality and were not added until after $1500,{ }^{32}$ raising even more questions concerning the style and craftmanship of both masterpieces. Apart from these obvious similarities there are also some small differences. The Archangel on the Greverade altar has a staff in his left hand, the Virgin Mary holds a book in her right hand, a dove is depicted above her head. Tallinn Gabriel holds a lily blossom in his left hand, and the Virgin Mary has a book not in her right but in her left hand. Despite these differences, the general posture and gesticulation, as well as the drapery falling from their slender bodies (including the pointed toe of Mary's right shoe peeping out from under her draped dress), are so similar as to be identical. Although the scene of the Annunciation of the Virgin Mary in Lübeck is executed with a more skilful hand and clearer contours, one cannot deny that they originated from the same workshop or that the composition in Tallinn is based on the Lübeck example.

Almost all authors have drawn attention to the German influence in the work of the Lübeck altar. The same can be said of Tallinn, where the local touch in iconography, colour and luxury goods characteristic to the Baltic region can hardly be ignored. First of all, let us mention the amber prayer beads held by a young donor dressed in green, kneeling before John the Baptist, ${ }^{33}$ in addition to which there is a certain respect for books in the Tallinn case, which are depicted on five occasions and which could be explained by the fact that it was commissioned for Tallinn's Dominican Monastery. ${ }^{34}$

31 De Vos, Memling, 90.

$32 \quad$ Ibidem, 326.

33 Ravo Reidna, Tallinna Mustpeade vennaskonna Maarja altar (Tallinn: Eesti Kunstimuuseum, 1995), 4.

34 Kerttu Palginõmm, "Luxusartikel auf dem Revaler Retabel des Meisters der Lucialegende als eine Einladung in die Stadt Brügge", Baltic Journal of Art History, 3 (2011), 111.
In her recent doctoral theses Tallinn's Kerttu Palginõmm has pointed out the abnormal number of luxury goods in the altarpiece. ${ }^{35}$ In her consideration the variety of rich accessories (gold, textiles, leather, etc.) exceeds standards familiar even to the taste of the Dutch bourgeoisie. In Tallinn, as in many other Nordic cities, the Renaissance and its idioms aimed first and foremost to satisfy representational needs, and so new art was imported into the Hanseatic town as a luxury item. ${ }^{36}$

Triumph der Wirklichkeit ${ }^{37}$, familiar to Flemish art, appears in Tallinn not so much in substantial roles but rather in particular places, something that has more to do with the decorative form than with the depths of artistic genius. To achieve such profundity one had leave Tallinn and start a career somewhere else, for example in Flanders, France or Spain where the sky was higher and the canvas broader, as can be seen in the case of Michel Sittow.

When speaking about Tallinn's Brotherhood of the Black Heads' St Mary's Altar we can most probably speak about the product of the workshop where, under supervision of the leading master and entrepreneur (Hans Memling?), a large number of the altarpieces produced were exported to different parts of the continent, and even more widely across the Atlantic ocean. Apart from Memling, possible collaborators in the opus magna (the largest altarpiece in the Baltic states) were Michael Sittow and the anonymous Master of the Holy Lucy legend in St James church in Bruges. In this way Tallinn's altar is a good example of the way in which paintings were produced in the 'art factories' of the period: one master might paint the saints' faces, another the clouds, a third the brocade patterns, a fourth the fabric folds. The leading master struck an agreement, came up with a 'programme', marked the main elements onto the panels and handed out the assignments.

In this way, distinguishing a specific talent from among others will usually remain a matter of discussion. Tallinn was a port and a wealthy commercial city at the foregates of the East, where the spirit

35 Kerttu Palginõmm, Pracht und Luxus zwischen Brügge und Reval: Retabel des Marienaltare der Bruderschaft der Revaler Schwarzenhäupter des Meisters der Legende der Hl. Lucia. PhD dissertation (Tartu: University of Tartu Press, 2020).

36 See: Juhan Maiste, "Die Renaissance in Tallinn. Ein neuer "Stil” in der alten Hansestadt", 27. 37 Dirk de Vos, Flämische Meister. Jan van Eyck, Rogier van der Weyden, Hans Memling (Köln: DuMont, 2002), 9. 
of the Renaissance took decades to penetrate and be assimilated. As a result of its remoteness Tallinn could only admire the glittering peaks from a distance as a sort of reflection, distinguishing the metropole from the province and its rhetorical code. Instead of an unobstructed view we are offered uncertain and often mixed values based on what we perceive through the veil of semantic research.

Juhan Maiste: Artistic Genius versus the Hanse Canon from the Late Middle Ages to the Easrly Modern Age in Tallinn Keywords: Artistic genius; Hanse Canon; workshop of Hans Memling; Michel Sittow; the Master of the Legend of Saint LUCY

\section{SUMMARY}

In the article, the author examines one of the most outstanding and problematic periods in the art history of Tallinn as a Hanseatic city, which originated, on the one hand, in the Hanseatic tradition and the medieval approach to Gothic transcendental realism, and on the other, in the approach typical of the new art cities of Flanders, i.e. to see a reflection of the new illusory reality in the pictures. A closer examination is made of two works of art imported to Tallinn in the late $15^{\text {th }}$ century, i.e. the high altar in the Church of the Holy Spirit by Bernt Notke and the altarpiece of Holy Mary, which was originally commissioned by the Brotherhood of Blackheads for the Dominican Monastery and is now in St Nicholas' Church. Despite the differences in the iconography and style of the two works, their links to tradition and artistic geography, which in this article are conditionally defined as the Hanse canon, are apparent in both of them.

The methods and rules for classifying the transition from the Middle Ages to the Modern Era were not critical nor exclusive. Rather they included a wide range of phenomena on the outskirts of the major art centres starting from the clients and ending with the semantic significance of the picture, and the attributes that were employed to the individual experiences of the different masters who were working together in the large workshops of Lübeck, and somewhat later, in Bruges and Brussels.

When 'reading' the Blackheads' altar, a question arises of three different styles, all of them were united by tradition and the way that altars were produced in the large workshops for the extensive art market that stretched from one end of the continent to the other and even further from Lima to Narva. Under the supervision of the leading master and entrepreneur (Hans Memling?) two other masters were working side by side in Bruges - Michel Sittow, who was born in Tallinn, and the Master of the Legend of Saint Lucy were responsible for executing the task.

In this article, the author has highlighted new points of reference, which on the one hand explain the complex issues of attribution of the Tallinn Blackheads' altar, and on the other hand, place the greatest opus in the Baltics in a broader context, where, in addition to aesthetic ambitions, both the client and the workshop that completed the order, played an extensive role. In this way, identifying a specific artist from among the others would usually remain a matter of discussion. Tallinn was a port and a wealthy commercial city at the foregates of the East where it took decades for the spirit of the Renaissance to penetrate and be assimilated. Instead of an unobstructed view we are offered uncertain and often mixed values based on what we perceive through the veil of semantic research.

\section{CV}

Juhan Maiste is Professor and Head of the Department of Art History at the University of Tartu. He has been a visiting professor at the universities of Helsinki, Turku, Oulu in Finland, Greifswald, La Sapienza in Rome and others. Doctor Honoris Causa of the Latvian Academy of Sciences. Main fields of study: classical ideal and its ,reflections in the Renaissance and Neoclassicism in Northern Europe and Baltic countries, manor architecture, the university landscape of the Enlightenment period. He is author of several monographs on philosophy and the poetics of art history, cultural heritage and 
landscape architecture and the editor-in-chief of the Baltic Journal of Art History. Recent works include: series of publications on the architectural and cultural history of Tartu University and the architecture of Johann Wilhelm Krause and Karl Morgenstern. 